[Review]

\title{
Significance of Intratracheal Instillation Tests for the Screening of Pulmonary Toxicity of Nanomaterials
}

\author{
Yasuo Morimoto $^{1 *}$, Hiroto Izumi ${ }^{1}$, Yukiko Yoshiura ${ }^{1}$, Yuri Fujisawa ${ }^{1}$ and Katsuhide Fujita ${ }^{2}$ \\ ${ }^{1}$ Department of Occupational Pneumology, Institute of Industrial Ecological Science, University of Occupational and \\ Environmental Health, Japan. Yahatanishi-ku, Kitakyushu 807-8555, Japan \\ ${ }^{2}$ National Institute of Advanced Industrial Science and Technology (AIST). Higashi, Tsukuba, Ibaraki 305-8565, Japan
}

\begin{abstract}
Inhalation tests are the gold standard test for the estimation of the pulmonary toxicity of respirable materials. Intratracheal instillation tests have been used widely, but they yield limited evidence of the harmful effects of respirable materials. We reviewed the effectiveness of intratracheal instillation tests for estimating the hazards of nanomaterials, mainly using research papers featuring intratracheal instillation and inhalation tests centered on a Japanese national project. Compared to inhalation tests, intratracheal instillation tests induced more acute inflammatory responses in the animal lung due to a bolus effect regardless of the toxicity of the nanomaterials. However, nanomaterials with high toxicity induced persistent inflammation in the chronic phase, and nanomaterials with low toxicity induced only transient inflammation. Therefore, in order to estimate the harmful effects of a nanomaterial, an observation period of 3 months or 6 months following intratracheal instillation is necessary. Among the endpoints of pulmonary toxicity, cell count and percentage of neutrophil, chemokines for neutrophils and macrophages, and oxidative stress markers are considered most important. These markers show persistent and transient responses in the lung from nanomaterials with high and low toxicity, respectively. If the evaluation of the pulmonary toxicity of nanomaterials is performed in not only the acute but also the chronic phase in order to avoid the bolus effect of intratracheal instillation and inflammatory-related factors that are used as endpoints of pulmonary toxicity, we speculate that intratracheal instillation tests can be useful for screening for the identification of the hazard of nanomaterials through pulmonary inflammation.
\end{abstract}

Keywords : nanomaterial, intratracheal instillation, inhalation, harmful effect.

(Received February 13, 2017, accepted April 13, 2017)

\section{Introduction}

Inhalation tests are the gold standard tests for estimating the harmful effects of nanomaterials, and test guidelines for short-term (5 days) inhalation tests for estimating the harmful effect of nanomaterials have been discussed in the Organization for Economic Cooperation and Development (OECD). However, it is actually impossible to perform inhalation tests for all nanomaterials because of the numerous kinds of nanomaterials, the high cost [1], and the necessity of facilities to house the large apparatus and the mastery of skills of the handler. On the other hand, intratracheal instillation tests, in which nanomaterials are exposed directly through the trachea, are useful for the investigation of lung disorders induced by nanomaterials. In addition, compared with inhalation tests, the expense is low and large facilities are not necessary [1]. There-

*Corresponding Author: Yasuo Mовгмото, MD, PhD, Department of Occupational Pneumology, Institute of Industrial Ecological Sciences, University of Occupational and Environmental Health, Japan. Yahatanishi-ku, Kitakyushu, 807-8555, Japan, Tel: +81-93-691-7136, E-mail address: yasuom@med.uoeh-u.ac.jp 
fore, the practical use of intratracheal instillation tests should be considered.

The results of intratracheal instillation tests are not equal to those of inhalation tests, even though the exposure route through the trachea is the same. It is important that the results of intratracheal instillation tests come close to or reflect the results of inhalation tests if they are to be used for the estimation of the harmful effects of nanomaterials. Here, mainly using Japanese national projects, we review how the experimental conditions of intratracheal instillation tests can make the results close to the results of inhalation tests, and how to interpret the results of intratracheal instillation tests in order to take advantage of them for the estimation of the harmful effect of nanomaterials.

\section{Intratracheal instillation tests}

In intratracheal instillation tests, rodents (especially rats) are exposed to suspensions of nanomaterials instilled through the trachea using endotracheal tubes under sufficient anesthesia. The cannula type and spray type of endotracheal tube are often used. After the intratracheal instillation of nanomaterials, rats are observed for certain periods of time, and lung tissue and bronchoalveolar lavage fluid (BALF) are used to examine the endpoints of inflammation, fibrosis and tumors in the lung [2].

\section{Endpoints of pulmonary toxicity of nanomaterials}

In lung disorders caused by nanomaterials, it is speculated that, like silica and asbestos, phagocytosis of nanomaterials induces the infiltration of inflammatory cells, including neutrophils and alveolar macrophages, and sustained or progressive inflammation is likely to cause lung injury and lead to irreversible changes, such as fibrosis and tumors [2]. In this process, alveolar macrophages engulf the nanomaterials and produce cytokines, including chemokines, and inflammatory cells accumulate in the lungs through these chemokines [3]. Sustained inflammation advances the lung injury with reactive oxygen species (ROS), and finally leads to fibrosis, which is formed by a disturbance of wound repair and respiratory tumor, which is formed by the genetic and epigenetic abnormality of epithelial cells [2]. Thus, it is speculated that sustained inflammation is connected with the onset and advance of lung disorders caused by nanomaterials. As we think that pulmonary toxicity is one set of irreversible changes, such as tumors, we reviewed sustained inflammation, which leads to irreversible changes, in the lung as the main endpoint of pulmonary toxicity.

\section{Dosage}

Intratracheal instillation of any nanomaterial, regardless of the degree of its pulmonary toxicity, may induce severe pulmonary inflammation and fibrosis if the dose of the nanomaterial is increased without an end. In order to determine the pulmonary toxicity of nanomaterials, therefore, it is necessary to have a limitation of the dosage. If the amount of deposited materials in the rat lung in an inhalation test is over a certain level, the pulmonary responses are influenced by not only the toxicity of the nanomaterials but also by their overload (surplus dose) $[4,5]$. An overload of materials leads to dysfunction of phagocytosis and migration of the alveolar macrophages, and this dysfunction is attended by a disturbance of the elimination of materials from the lung and the creation of the pulmonary response. There has been no consideration of overload theory in intratracheal instillation tests until now because the technique is not very old. However, considering the sustained and severe inflammation caused by surplus doses of nanomaterials, one can easily imagine that there is at least a possibility of overload in intratracheal instillation tests. We performed an intratracheal instillation of $\mathrm{TiO}_{2}$ nanomaterials (low in toxicity among nanomaterials) in rats, and doses of $1 \mathrm{mg}$ and $3 \mathrm{mg} /$ rat induced the delay of clearance of the $\mathrm{TiO}_{2}$ nanomaterials, while doses of $0.1 \mathrm{mg}$ and $0.2 \mathrm{mg} /$ rat did not [6]. As in another intratracheal instillation test of a nanomaterial with low toxicity, fullerene, a dose of more than $1 \mathrm{mg} /$ rat caused sustained inflammation in rat lung [7]. Therefore, doses of $1 \mathrm{mg} / \mathrm{rat}$ $(5 \mathrm{mg} / \mathrm{kg}$ ) may be useful as the maximum dose in intratracheal instillation tests, at least partially in order to examine the pulmonary toxicity of nanomaterials under the same weight base.

\section{Observation time}

In general, nanomaterials induce pulmonary inflammation just after intratracheal instillation, at any degree of pulmonary toxicity. This response is due to a bolus 
effect, a reaction stimulated by an injection of a large amount of material all at once. It is thought that this bolus effect masks the original toxicity of nanomaterials. We conducted intratracheal instillations of four nanomaterials with different toxicities at the maximum dose of $1 \mathrm{mg}$ to rats and examined lung inflammation from 3 days to 6 months [8-10]. Not only nanomaterials with a relatively high toxicity, such as nickel oxide $(\mathrm{NiO})$ and cerium oxide $\left(\mathrm{CeO}_{2}\right)$, but also those with a relatively low toxicity, such as titanium dioxide $\left(\mathrm{TiO}_{2}\right)$ and zinc oxide $(\mathrm{ZnO})$, induced pulmonary neutrophil inflammation at 3 days and 7 days. Especially in the acute phase, intratracheal instillation of $\mathrm{ZnO}$ induced the most severe inflammation among the 4 nanomaterials (Fig. 1). Therefore, it is difficult to estimate pulmonary toxicity in the acute phase just after intratracheal instillation, but in the chronic phase ( 3 or 6 months), nanomaterials of $\mathrm{NiO}$ and $\mathrm{CeO}_{2}$ induced sustained pulmonary inflammation from the third day. Intratracheal exposure to $\mathrm{NiO}$ nanoparticles induced pulmonary inflammation in rats, and the peak of inflammation was at 3 months post exposure [1]. On the other hand, pulmonary inflammation by nanomaterials of $\mathrm{TiO}_{2}$ and $\mathrm{ZnO}$ disappeared in that chronic phase. Creutzenberg et al conducted an intratracheal instillation study of $\mathrm{TiO}_{2}$ and quartz as a positive control, and observed the results until 90 days post exposure. Neutrophil influx into the lung exposed to quartz increased in a time dependent fashion. In the meantime, in micron-sized $\mathrm{TiO}_{2}$ as a material with low toxicity, only a transient inflammation was observed
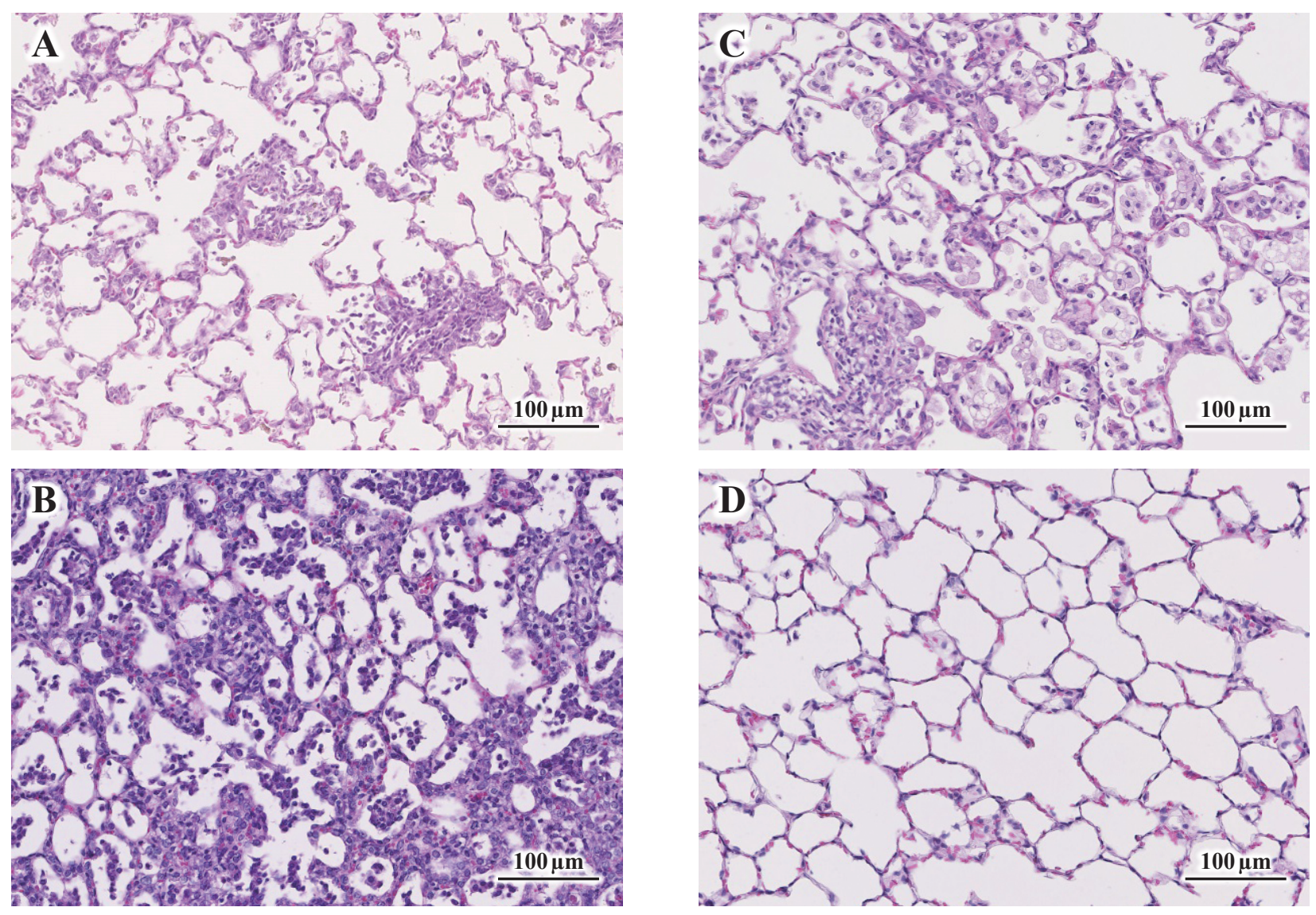

Fig. 1. Representative photomicrographs of H\&E-stained lung tissue in rats following intratracheal instillation of nanomaterials. A: $1 \mathrm{mg}-\mathrm{NiO}$-exposed lung at 3 days. B: $1 \mathrm{mg}-\mathrm{ZnO}$ nanoparticle-exposed lung at 3 days. C: $1 \mathrm{mg}-\mathrm{NiO}$-exposed lung at 3 months. D: $1 \mathrm{mg}-\mathrm{ZnO}$ nanoparticle-exposed lung at 3 months. Compared with $\mathrm{NiO}$, a nanomaterial with high toxicity, exposure to $\mathrm{ZnO}$, a nanomaterial with low toxicity, induced more severe inflammation in the lung at 3 days after intratracheal instillation. However, the pulmonary inflammation in $\mathrm{ZnO}$-exposed lung disappeared at 3 months, while the inflammation in NiO-exposed lung increased significantly. 
just after the instillation [11]. Warheit et al conducted an intratracheal instillation of a variety of $\mathrm{TiO}_{2}$ from 24 hours to 3 months, and pulmonary inflammation lasted for 1 month [12]. When Kobayashi et al performed an intratracheal instillation of $\mathrm{TiO}_{2}$ nanoparticles with different primary diameters and agglomerated diameters, pulmonary inflammation by all the $\mathrm{TiO}_{2}$ nanoparticles disappeared at 1 month post-instillation [13].

Meanwhile, there are materials with high toxicity with which the appearance of pulmonary inflammation is delayed, although there are not nanoparticles. We conducted intratracheal instillations of crystalline silica at the dose of $1 \mathrm{mg}$ to rats and examined the lung inflammation from 3 days to 6 months. Figure 2 shows the pathological features in the lung exposed to crystalline silica in not only the acute but also the chronic phase. Exposure

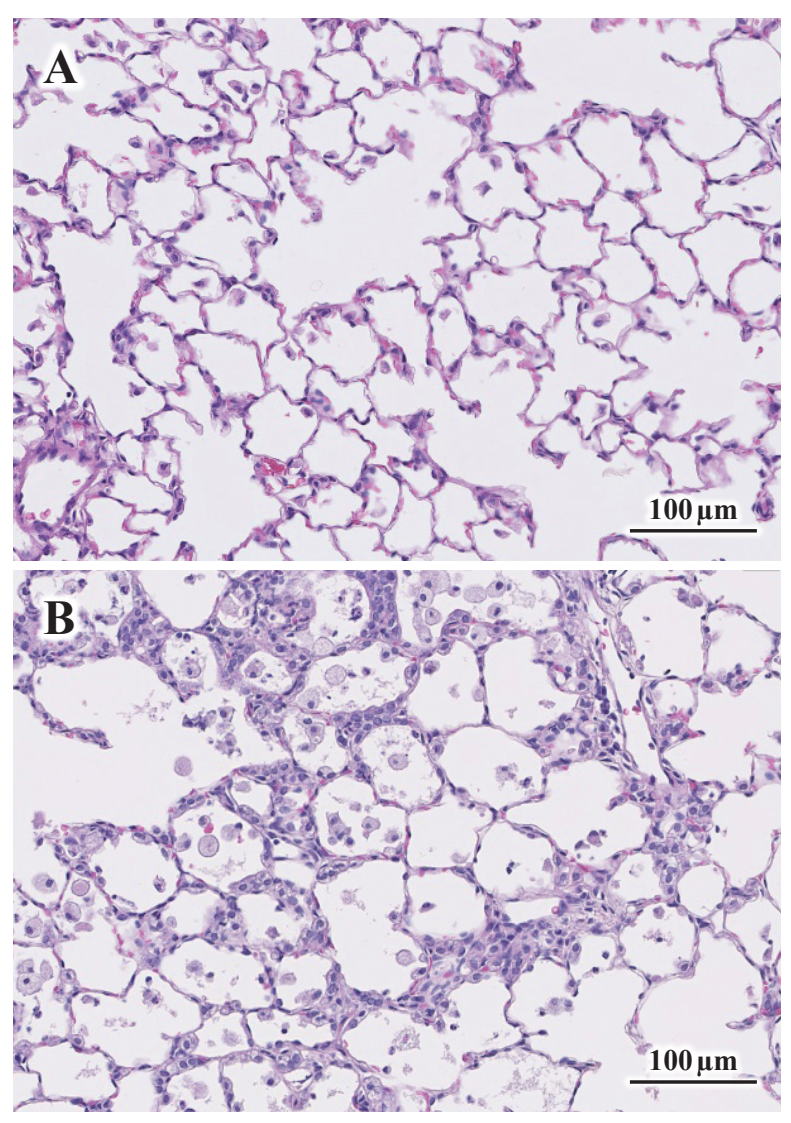

Fig. 2. Representative photomicrographs of H\&E-stained lung tissue in rats following intratracheal instillation of crystalline silica. A: $1 \mathrm{mg}$-crystalline silica-exposed lung at 1 week. B: $1 \mathrm{mg}$-crystalline silica-exposed lung at 6 months. Crystalline silica induced advance of pulmonary inflammation 3 months after intratracheal instillation. to crystalline silica caused no, or minimum, pulmonary inflammation in the lung in the acute phase (1 week), but it induced pulmonary inflammation, including accumulation of foamy macrophages, in the chronic phase (6 months). This pulmonary inflammation is usually observed at 3 and 6 months after intratracheal instillation. Considering the onset and sustenance of pulmonary inflammation induced by nanomaterials and materials with high toxicity such as crystalline silica, it is important to keep a sufficient observation period of 3 to 6 months in order to examine their pulmonary toxicity.

\section{Distribution of deposited nanomaterials in the lung}

Nanomaterials deposited in the lung just after intratracheal instillation are mainly distributed in the centrilobular spaces, which are the neighboring alveolus area around the peripheral respiratory tract. The accumulation of inflammatory cells, such as neutrophils and macrophages, was observed in this centrilobular space, and the accumulation of nanomaterials and macrophages with phagocytosis of nanomaterials accompanied this inflammation $[14,15]$. As nanomaterials were observed mainly in centrilobular lesions just after the end of the inhalation exposure [16-19], we think that there is not much difference in distribution between intratracheal instillation and inhalation. However, some inflammatory lesions were observed not only deep in the alveolar wall but also in the subpleural area $[17,18]$.

There is a little difference in distribution between types of endotracheal tube (Fig. 3). We examined the distribution of multiwall carbon nanotube (MWCNT) in the lung following intratracheal instillation using two different types of endotracheal tube, cannula and spray. Fundamentally, both types of endotracheal tube showed that the pattern of distribution of the deposited nanomaterials in the lung was centrilobular. Although there was only a little difference, in the cannula type this distribution shifted slightly to the proximal site, although a difference in deposition between lobes was not observed. In the spray type, the distribution shifted to the distal site and deposition of MWCNT was close to the pleura, although the deposition of nanomaterials shifted more into the lower lobes than the other lobes. Fujita et al reported that intratracheal injection of short MWCNT using an aerosolizing microsprayer induced 
time-dependent pleural inflammation [20]. There are reports of the deposition of MWCNT in the pleura in the acute phase after intratracheal injection of MWCNT using the spray type $[20,21]$, and that same injection of MWCNT induced malignant mesothelioma in rat lung [22]. On the other hand, in a 24-month inhalation study MWCNT did not induce malignant mesothelioma but did induce pulmonary tumors [23]. Considering the results of the spray type injection and inhalation collectively, the spray type injection might induce a surplus translocation of MWCNT into the pleura cavity compared with inhalation, and there is a possibility that the surplus MWCNT in the pleura may be related to pleural tumors. However, there are few such reports, and further examination is necessary.
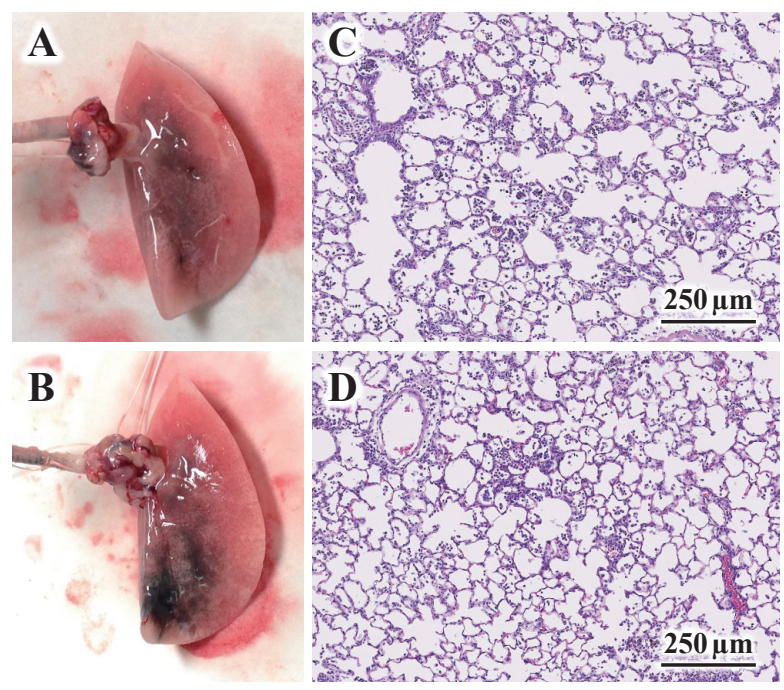

Fig. 3. Representative photomicrographs of H\&E-stained lung tissue in rat. A: Macroscopic finding of lung tissue following intratracheal instillation of MWCNT using cannula type, B: Macroscopic finding of lung tissue following intratracheal instillation of MWCNT using spray type. In the spray type, the area of distribution of inflammation shifted to the distal site, and deposition of MWCNT is closer to the pleura, compared with the cannula type. Deposition of nanomaterials shifted to the lower lobes compared with other lobes in the spray type. C: Lung tissue following intratracheal instillation of MWCNT using cannula type. D: Lung tissue following intratracheal instillation of MWCNT using spray type. Distribution of infiltration of inflammatory cells in the lung were mainly centrilobular lesions in both methods. Geometric mean diameter, length and specific surface area are $52 \mathrm{~nm}$, $2.16 \mu \mathrm{m}$ and $23.0 \mathrm{~m}^{2} / \mathrm{g}$, respectively. MWCNT: multiwall carbon nanotube.

\section{Predictive markers of pulmonary toxicity}

As many papers focus on pulmonary inflammation in relation to the pulmonary toxicity of nanomaterials $[8-10$, $12,13,18]$, we think that factors related to pulmonary inflammation, especially neutrophil inflammation, are useful for markers of the pulmonary toxicity of nanomaterials (Table 1). An important issue in the identification of the pulmonary toxicity of nanomaterials is whether or not exposure to a nanomaterial induces sustained pulmonary inflammation in an intratracheal instillation test, and it is also important that the persistency of pulmonary inflammation or expression of inflammatory factors is related to the degree of the pulmonary toxicity. We think that persistency of pulmonary inflammation and its related factors appear in not only the acute phase (3 days to 1 month after intratracheal instillation) but also in the chronic phase ( 3 months to 6 months after intratracheal instillation) in intratracheal instillation tests.

Table 1. Endpoints of pulmonary toxicity through pulmonary inflammation

\begin{tabular}{|c|c|}
\hline Endpoints & $\begin{array}{l}\text { Sustained responses } \\
\text { by nanomaterials }\end{array}$ \\
\hline $\begin{array}{l}\text { Total cell counts in } \\
\text { BALF }\end{array}$ & $\begin{array}{l}\text { Nanomaterials with high toxicity: } \\
\text { Sustained response }( \pm) \\
\text { Nanomaterials with low toxicity: } \\
\text { Sustained response }(-)\end{array}$ \\
\hline $\begin{array}{l}\text { Number of macrophage } \\
\text { in BALF }\end{array}$ & $\begin{array}{l}\text { Nanomaterials with high toxicity: } \\
\text { Sustained response }( \pm) \\
\text { Nanomaterials with low toxicity: } \\
\text { Sustained response }(-)\end{array}$ \\
\hline $\begin{array}{l}\text { Number of Neutrophils } \\
\text { in BALF } \\
\text { Percentage of } \\
\text { neutrophils in BALF }\end{array}$ & $\begin{array}{l}\text { Nanomaterials with high toxicity: } \\
\text { Sustained response }(+) \\
\text { Nanomaterials with low toxicity: } \\
\text { Sustained response }(-)\end{array}$ \\
\hline $\begin{array}{l}\text { Proinflammaotry } \\
\text { cytokines in BALF } \\
\text { (IL-1, TNF, IL-6) }\end{array}$ & $\begin{array}{l}\text { Nanomaterials with high toxicity: } \\
\text { Sustained response }(-) \\
\text { Nanomaterials with low toxicity: } \\
\text { Sustained response }(-)\end{array}$ \\
\hline $\begin{array}{l}\text { Chemokines in BALF } \\
\text { (CINC, KC) }\end{array}$ & $\begin{array}{l}\text { Nanomaterials with high toxicity: } \\
\text { Sustained response }(+) \\
\text { Nanomaterials with low toxicity: } \\
\text { Sustained response }(-)\end{array}$ \\
\hline HO-1 in BALF & $\begin{array}{l}\text { Nanomaterials with high toxicity: } \\
\text { Sustained response }(+) \\
\text { Nanomaterials with low toxicity: } \\
\text { Sustained response }(-)\end{array}$ \\
\hline
\end{tabular}

Sustained response: Response to last more than 1 month after end of exposure. BALF: bronchoalveolar lavage fluid, IL: interleukin, TNF: tumor necrosis factor, CINC: cytokine-induced neutrophil chemoattractant, $\mathrm{KC}$ : keratinocyte chemoattractant, HO-1: heme oxygenase-1 
Because this pulmonary toxicity marker is fundamentally predictive, it is not so important to know the characteristics that reflect the activity of a disease or to identify the disease specificity; it is important to keep the superiority of sensitivity and specificity of the pulmonary toxicity of nanomaterials. Judging with a predictive marker using not just one point of observation time but several points of observation time (not only acute but also chronic phase) due to sustained changes in the marker, may lead to the reliability of a predictive marker.

We consider that neutrophil cell counts, percentage of neutrophils, cytokine-induced neutrophil chemoattractant (CINC)-family, and heme oxygenase-1 (HO-1) in BALF are good predictive markers of the pulmonary toxicity of nanomaterials (Fig. 4, Table 2). Several nanomaterials have been used to examine the relationship between the toxicity of nanomaterials and pulmonary inflammation [15, 24]. $\mathrm{NiO}[25]$ and $\mathrm{CeO}_{2}$ [9], nanoparticles with high toxicity considered in the data of inhalation tests, induced sustained changes in the above markers in the $\mathrm{BALF}$, and $\mathrm{TiO}_{2}$, fullerene [7] and $\mathrm{ZnO}$ [8], nanoparticles with low toxicity considered in the data of inhalation tests, induced only transient changes. These neutrophil influxes, CINC and HO-1 expression in BALF corresponded to pulmonary infiltration as pathological features. In many studies, asbestos and crystalline silica, well-known materials with high toxicity, induced sustained changes in neutrophil influx, CINC, and HO-1 in the lung, although these materials are not nanomaterials $[11,26]$. On the other hand, intratracheal instillation of micron-sized $\mathrm{TiO}_{2}$ did induce transient changes in the above markers. As for chemokines other than CINC, Keratinocyte derived chemokines $(\mathrm{KC})$ have been reported to increase persistently in lung following intratracheal instillation of quartz. Seiffert et al [27] conducted an intratracheal instillation test of silver nanoparticles, and the exposure induced a transient $\mathrm{KC}$ concentration in BALF, while the chemokine expression pattern was accompanied by neutrophil influx in the lung. An inhalation exposure of $\mathrm{ZnO}$ nanoparticles with low toxicity did not induce neutrophil influx or an increase the concentration of KC in BALF [28].

Although macrophage counts and total cell counts in BALF are known to be representative inflamma-
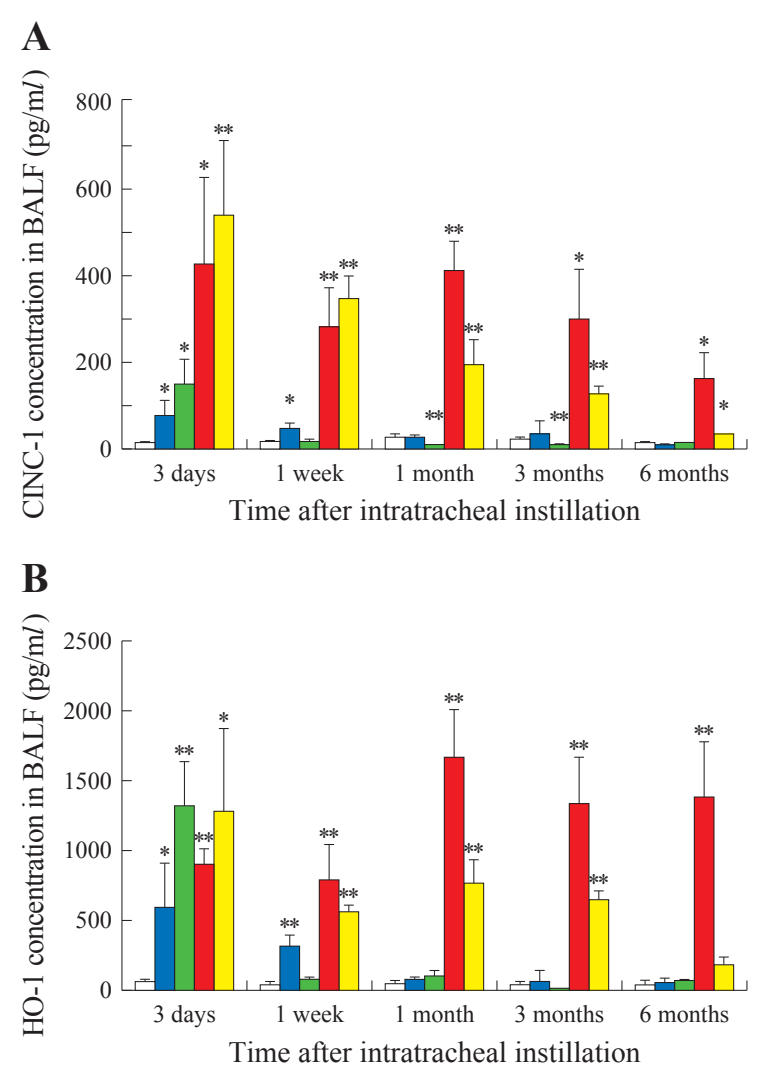

Fig. 4. Neutrophil-related factors in BALF. A: CINC-1 concentration of BALF following intratracheal instillation of $\mathrm{TiO}_{2}, \mathrm{ZnO}, \mathrm{NiO}$ and $\mathrm{CeO}_{2}$ nanoparticles. B: HO- 1 concentration of BALF following intratracheal instillation of $\mathrm{TiO}_{2}$, $\mathrm{ZnO}, \mathrm{NiO}$ and $\mathrm{CeO}_{2}$ nanoparticles. Intratracheal instillation of $\mathrm{NiO}$ and $\mathrm{CeO}_{2}$ induced sustained expression of CINC-1 and $\mathrm{HO}-1$, whereas $\mathrm{TiO}_{2}$ and $\mathrm{ZnO}$ nanoparticles induced transient expression. $\square$ : Negative Control, $\square$ : $\mathrm{TiO}_{2}, \square$ : $\mathrm{ZnO}, \square: \mathrm{NiO}, \square: \mathrm{CeO}_{2}, *: P<0.05$ versus negative control, $* *: P<0.01$ versus negative control.

Table 2. Physicochemical properties of nanomaterials used in Fig. 4

\begin{tabular}{lllllll}
\hline $\begin{array}{l}\text { Physicochemical } \\
\text { properties }\end{array}$ & $\mathrm{TiO}_{2}$ & & $\mathrm{ZnO}$ & $\mathrm{NiO}$ & $\mathrm{CeO}_{2}$ \\
\hline Primary diameter & $\begin{array}{l}\text { Short } 12 \\
\text { Long } 55\end{array}$ & $\mathrm{~nm}$ & $35 \mathrm{~nm}$ & 19 & $\mathrm{~nm}$ & $7.8 \mathrm{~nm}$ \\
& $44.9 \mathrm{~nm}$ & $33 \mathrm{~nm}$ & $59.7 \mathrm{~nm}$ & $10.0 \mathrm{~nm}$ \\
$\begin{array}{l}\text { Secondary } \\
\text { particle diameter }\end{array}$ & & & & & \\
$\begin{array}{l}\text { Specific surface } \\
\text { area (BET) }\end{array}$ & $111 \mathrm{~m}^{2} / \mathrm{g}$ & $31 \mathrm{~m}^{2} / \mathrm{g}$ & $57 \mathrm{~m}^{2} / \mathrm{g}$ & $101 \mathrm{~m}^{2} / \mathrm{g}$ \\
\hline
\end{tabular}


tory indexes, these indexes do not always correspond to the pulmonary toxicity of nanomaterials. Exposure to chemicals is reported in many papers to increase the macrophage cell count in BALF, but some chemicals decreased the macrophage cell count in animal models. Intratracheal instillation and inhalation of asbestos reduced the macrophage cell count in BALF [29, 30]. Crystalline silica also decreased the number of alveolar macrophages through apoptosis [31, 32], and this decrease in macrophages may have been cell death due to the toxicity of the particles. It has also been reported that inhalation exposure of asbestos does not change the total cell counts in BALF [30]. The changes in total cell counts in BALF may affect the influx of not only macrophages but also neutrophils, and that is not sufficient to reflect the neutrophil inflammation.

There are reports that the proinflammatory cytokines interleukin-1 (IL-1), IL-6 and tumor necrosis factor (TNF) were upregulated in the acute period in animal models exposed to inhaled crystalline silica and $\mathrm{TiO}_{2}$ [33-35]. These transient upregulations of proinflammaory cytokines may play a key role in sustained pulmonary inflammation, but changes in proinflammatory cytokines may not sufficiently reflect the pulmonary toxicity of nanomaterials due to the short response period, and may not be useful as predictive markers of the pulmonary toxicity of nanomaterials.

\section{Summary}

We reviewed the usefulness of intratracheal instillation tests for the screening of hazard assessments of nanomaterials. Sustained pulmonary inflammation, which leads to lung tumor, is considered to be the endpoint of pulmonary toxicity, and that is discussed in the relationship between the toxicity of nanomaterials and pulmonary inflammation. In the data of inhalation tests, nanomaterials with high toxicity induced sustained changes in the kinetics of neutrophil counts, percentages of neutrophils, chemokines in neutrophils and macrophages, and HO-1 in BALF, while nanomaterials with low toxicity induced transient changes. Taken together, we suggest that, based on pulmonary inflammation, the ranking of the hazards of nanomaterials by intratracheal instillation corresponds to that by inhalation, and that intratracheal instillation tests can be useful for screening the hazards of nanomaterials.

As for quantitative pulmonary inflammation in both intratracheal instillation and inhalation tests, neutrophil inflammation and its related factors in the lung tissue are higher in intratracheal instillation tests than in inhalation tests. A significantly greater amount of neutrophils in BALF following the intratracheal instillation of $\mathrm{TiO}_{2}$ nanoparticles was observed in comparison to inhalation, even though the initial lung burdens were the same [10]. Silva et al [14] also showed that the infiltration of inflammatory cells following the intratracheal instillation of multiwall carbon nanotube (MWCNT) was greater than that following inhalation of MWCNT. Our experiments with $\mathrm{NiO}$ and $\mathrm{TiO}_{2}$ nanoparticles showed a similar tendency [18]. Considering these data, intratracheal instillation tests may not become alternative methods to inhalation tests for the assessment of the hazards of the pulmonary toxicity of nanomaterials, but they may be useful for screening for hazard assessment of the pulmonary toxicity of nanomaterials.

\section{Acknowledgment}

This work was supported by a project entitled "Innovative carbon nanotubes composite materials project toward achieving a low-carbon society (P10024)" which was commissioned by the New Energy and Industrial Technology Development Organization (NEDO) in Japan.

\section{Conflicts of interest}

The authors declare no conflict of interest.

\section{References}

1. Morimoto Y, Izumi H, Yoshiura Y, Fujishima K, Yatera K \& Yamamoto K (2016): Usefulness of intratracheal instillation studies for estimating nanoparticle-induced pulmonary toxicity. Int J Mol Sci 17: E165

2. Morimoto Y, Izumi H \& Kuroda E (2014): Significance of persistent inflammation in respiratory disorders induced by nanoparticles. J Immunol Res 2014: 962871

3. Nishi K, Morimoto Y, Ogami A et al (2009): Expression of cytokine-induced neutrophil chemoattractant in rat lungs by intratracheal instillation of nickel oxide 
nanoparticles. Inhal Toxicol 21: 1030-1039

4. Morrow PE, Muhle H \& Mermelstein R (1991): Chronic inhalation study findings as a basis for proposing a new occupational dust exposure limit. J Am Coll Toxicol 10: 279-290

5. Bellmann B, Muhle H, Creutzenberg O \& Mermelstein R (1992): Irreversible pulmonary changes induced in rat lung by dust overload. Environ Health Perspect 97: 189-191

6. Oyabu T, Morimoto Y, Hirohashi M, Horie M, Kambara T, Lee BW, Hashiba M, Mizuguchi Y, Myojo T \& Kuroda E (2013): Dose-dependent pulmonary response of welldispersed titanium dioxide nanoparticles following intratracheal instillation. J Nanopart Res 15: 1600

7. Morimoto Y, Hirohashi M, Ogami A et al (2010): Inflammogenic effect of well-characterized fullerenes in inhalation and intratracheal instillation studies. Part Fibre Toxicol 7: 4

8. Morimoto Y, Izumi H, Yoshiura Y et al (2016): Evaluation of pulmonary toxicity of zinc oxide nanoparticles following inhalation and intratracheal instillation. Int J Mol Sci 17: E1241

9. Morimoto Y, Izumi H, Yoshiura Y et al (2015): Pulmonary toxicity of well-dispersed cerium oxide nanoparticles following intratracheal instillation and inhalation. J Nanopart Res 17: 442

10. Morimoto Y, Izumi H, Yoshiura Y et al (2016): Comparison of pulmonary inflammatory responses following intratracheal instillation and inhalation of nanoparticles. Nanotoxicology 10: 607-618

11. Creutzenberg O, Hansen T, Ernst H, Muhle H, Oberdörster G \& Hamilton R (2008): Toxicity of a quartz with occluded surfaces in a 90-day intratracheal instillation study in rats. Inhal Toxicol 20: 995-1008

12. Warheit DB, Brock WJ, Lee KP, Webb TR \& Reed KL (2005): Comparative pulmonary toxicity inhalation and instillation studies with different $\mathrm{TiO}_{2}$ particle formulations: impact of surface treatments on particle toxicity. Toxicol Sci 88: 514-524

13. Kobayashi N, Naya M, Endoh S, Maru J, Yamamoto K \& Nakanishi J (2009): Comparative pulmonary toxicity study of nano- $\mathrm{TiO}_{2}$ particles of different sizes and agglomerations in rats: different short- and long-term post-instillation results. Toxicology 264: 110-118

14. Silva RM, Anderson DS, Franzi LM, Peake JL, Edwards PC, Van Winkle LS \& Pinkerton KE (2015): Pulmonary effects of silver nanoparticle size, coating, and dose over time upon intratracheal instillation. Toxicol Sci 144: $151-162$

15. Tomonaga T, Izumi H, Yoshiura Y et al (2017): Assessment of pulmonary toxicity induced by inhaled toner with external additives. Biomed Res Int 2017: 4245309

16. Bermudez E, Mangum JB, Asgharian B, Wong BA, Reverdy EE, Janszen DB, Hext PM, Warheit DB \& Everitt JI (2002): Long-term pulmonary responses of three laboratory rodent species to subchronic inhalation of pigmentary titanium dioxide particles. Toxicol Sci 70: 86-97

17. Bermudez E, Mangum JB, Wong BA, Asgharian B, Hext PM, Warheit DB \& Everitt JI (2004): Pulmonary responses of mice, rats, and hamsters to subchronic inhalation of ultrafine titanium dioxide particles. Toxicol Sci 77: 347-357

18. Shvedova AA, Kisin E, Murray AR et al (2008): Inhalation vs. aspiration of single-walled carbon nanotubes in C57BL/6 mice: inflammation, fibrosis, oxidative stress, and mutagenesis. Am J Physiol Lung Cell Mol Physiol 295: L552-L565

19. Nørgaard AW, Larsen ST, Hammer M, Poulsen SS, Jensen KA, Nielsen GD \& Wolkoff P (2010): Lung damage in mice after inhalation of nanofilm spray products: the role of perfluorination and free hydroxyl groups. Toxicol Sci 116: 216-224

20. Fujita K, Fukuda M, Endoh S, Maru J, Kato H, Nakamura A, Shinohara N, Uchino K \& Honda K (2016): Pulmonary and pleural inflammation after intratracheal instillation of short single-walled and multi-walled carbon nanotubes. Toxicol Lett 257: 23-37

21. Xu J, Futakuchi M, Shimizu H et al (2012): Multi-walled carbon nanotubes translocate into the pleural cavity and induce visceral mesothelial proliferation in rats. Cancer Sci 103: 2045-2050

22. Suzui M, Futakuchi M, Fukamachi K et al (2016): Multiwalled carbon nanotubes intratracheally instilled into the rat lung induce development of pleural malignant mesothelioma and lung tumors. Cancer Sci 107: 924-935

23. Kasai T, Umeda Y, Ohnishi M, Mine T, Kondo H, Takeuchi T, Matsumoto M \& Fukushima S (2016): Lung carcinogenicity of inhaled multi-walled carbon nanotube in rats. Part Fibre Toxicol 13: 53

24. Morimoto Y, Ogami A, Todoroki M et al (2010): Expression of inflammation-related cytokines following intra- 
tracheal instillation of nickel oxide nanoparticles. Nanotoxicology 4: 161-176

25. Jeong J, Kim J, Seok SH \& Cho WS (2016): Indium oxide $\left(\mathrm{In}_{2} \mathrm{O}_{3}\right)$ nanoparticles induce progressive lung injury distinct from lung injuries by copper oxide $(\mathrm{CuO})$ and nickel oxide (NiO) nanoparticles. Arch Toxicol 90: $817-828$

26. Cyphert JM, Padilla-Carlin DJ, Schladweiler MC, Shannahan JH, Nyska A, Kodavanti UP \& Gavett SH (2012): Long-term response of rats to single intratracheal exposure of Libby amphibole or amosite. J Toxicol Environ Health A 75: 183-200

27. Seiffert J, Hussain F, Wiegman C et al (2015): Pulmonary toxicity of instilled silver nanoparticles: influence of size, coating and rat strain. PLoS One 10: e0119726

28. Adamcakova-Dodd A, Stebounova LV, Kim JS, Vorrink SU, Ault AP, O’Shaughnessy PT, Grassian VH \& Thorne PS (2014): Toxicity assessment of zinc oxide nanoparticles using sub-acute and sub-chronic murine inhalation models. Part Fibre Toxicol 11: 15

29. Tan RJ, Fattman CL, Watkins SC \& Oury TD (2004): Redistribution of pulmonary EC-SOD after exposure to asbestos. J Appl Physiol 97: 2006-2013

30. Haegens A, van der Vliet A, Butnor KJ et al (2005): Asbestos-induced lung inflammation and epithelial cell proliferation are altered in myeloperoxidase-null mice. Cancer Res 65: 9670-9677

31. Wang H \& Leigh J (2006): Effects of nitric oxide synthase inhibitor omega-nitro-L-arginine methyl ester, on silica-induced inflammatory reaction and apoptosis. Part Fibre Toxicol 3: 14

32. Leigh J, Wang H, Bonin A, Peters M \& Ruan X (1997): Silica-induced apoptosis in alveolar and granulomatous cells in vivo. Environ Health Perspect 105 (Suppl 5): $1241-1245$

33. Roursgaard M, Jensen KA, Poulsen SS, Jensen NE, Poulsen LK, Hammer M, Nielsen GD \& Larsen ST (2011): Acute and subchronic airway inflammation after intratracheal instillation of quartz and titanium dioxide agglomerates in mice. Scientific World Journal 11: $801-825$

34. Park EJ, Yoon J, Choi K, Yi J \& Park K (2009): Induction of chronic inflammation in mice treated with titanium dioxide nanoparticles by intratracheal instillation. Toxicology 260: 37-46

35. Gustafsson A, Lindstedt E, Elfsmark LS \& Bucht A (2011): Lung exposure of titanium dioxide nanoparticles induces innate immune activation and long-lasting lymphocyte response in the Dark Agouti rat. J Immunotoxicol 8: 111-121 
気管内注入試験は，工業用ナノ材料の肺有害性スクリーニングとして有用である

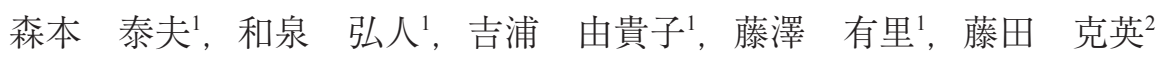

1産業医科大学 産業生態科学研究所 呼吸病態学

2産業技術総合研究所

要旨：吸入性化学物質の肺有害性を評価するゴールドスタンダード試験は, 吸入ばく露試験である。一方,気 管内注入試験は, 用量反応関係, メカニズムの解明など広く実施されているが, 肺有害性に関するエビデンスが限ら れている. 我々は, 気管内注入試験と吸入ばく露試験を比較した報告を中心に工業用ナノ材料の肺有害性評価とし て気管内注入試験の有用性を解説する。吸入ばく露試験と比較して, 気管内注入試験は, 対象となるナノ材料を一挙 に注入するため, ナノ材料の有害性のレベルにかかわらず, 注入直後(注入後 3 日から 1 週間)に肺炎症を引き起こす. しかし肺有害性の強いナノ材料は, 急性期のみならず慢性期 (注入後3 月から 6 个月) まで持続性炎症を示すが, 肺 有害性の弱いナノ材料は, 急性期の一過性炎症のみである. 従って, 肺有害性を評価するための注入後の観察期間 は, 慢性期まで行うことが重要と思われる. 肺有害性の評価項目では, 気管支肺胞洗浄液中の好中球数, 比率, 好中球 やマクロファージのケモカイン, 酸化ストレスマーカーがあげられ, 肺有害性の強い物質では, これらの評価項目が 慢性期に至るまで持続的反応を示す。一方, 肺有害性が弱い物質では, 急性期のみの反応となる。よって, 気管内注 入試験で, 慢性期まで観察し, 炎症関連因子の持続反応性を評価することで, 気管内注入試験が, 吸入ばく露試験の肺 有害性のスクリーニング試験として有用であることが示唆される.

キーワード：ナノマテリアル, 気管内注入, 吸入, 有害性.

J UOEH(産業医大誌) 39(2)：123-132（2017） 